\title{
Perlindungan Konsumen terhadap Kelangkaan Produk Non Pokok Akibat Penimbunan yang Dilakukan oleh Pelaku Usaha
}

\author{
Satria Aldyan Firmanda*, Iwan Erar Joesoef \\ Fakultas Hukum Universitas Pembangunan Nasional Veteran Jakarta \\ *Correspondence email: satriaaldyanf@upnvj.ac.id, iwan.erar@upnvj.ac.id
}

\begin{abstract}
Abstrak. Pada tahun 2020 Walls Indonesia meluncurkan Kembali produk legendaris mereka yaitu Ice Cream "Viennetta" yang terkenal pada periode 90 -an. namun hal ini disalah gunakan oleh oknum jahat yang tidak bertanggung jawab demi kepentingannya sendiri. Oknum tersebut memanfaatkan antusiasme masyarakat terhadap kembalinya produk legendaris dari Walls Indonesia yaitu Ice Cream Viennetta dengan cara menimbun barang tersebut dan menjualnya dengan harga yang lebih mahal. Sebenarnya peraturan mengenai perlindungan konsumen terhadap penimbunan barang sudah mendapat perlindugan dari Kementerian Perdagangan dalam Peraturan Menteri Perdagangan Nomor 20/M-DAG/PER/3/2017 tentang Pendaftaran Pelaku Usaha Distribusi Barang Kebutuhan Pokok, namun sayangnya peraturan tersebut hanya berlaku terhadap barang pokok saja. Maka dari itu penelitian ini bertujuan untuk memberi edukasi terhadap konsumen agar mengetahui hak-haknya sebagai konsumen dan agar pemerintah dapat membahas ulang peraturan mengenai penimbunan barang agar dapat diperluas tidak hanya sebatas barang kebutuhan pokok saja dengan menggunakan metode penelitian Yuridis Normatif dan menggunakan pendekatan undang-undang, penulis mendapatkan hasil dari penelitian ini bahwa konsumen masih bisa mendapatkan perlindungan hukum terhadap kelangkaan dari suatu barang non pokok dengan menggunakan Undang-Undang Perdagangan, Undang-Undang Perlindungan Konsumen, dan Undang-Undang Persaingan Usaha.
\end{abstract}

Kata kunci: Penimbunan Barang, Perlindungan Konsumen, Persaingan Usaha Tidak Sehat

Abstract. In 2020 Walls Indonesia re-launched their legendary product, "Viennetta" Ice Cream which was famous in the 90 s. but this is misused by bad people who are not responsible for their own interests. They took advantage of the public's enthusiasm for the return of the legendary product from Walls Indonesia, namely Viennetta Ice Cream by hoarding these items and selling them at a higher price. The regulations regarding consumer protection against hoarding of goods have received protection from the Ministry of Trade in the Regulation of the Minister of Trade Number 20/M-DAG/PER/3/2017 concerning Registration of Business Actors in the Distribution of Staple Needs, but unfortunately this regulation only applies to basic goods. Therefore, this study aims to educate consumers in order to know their rights as consumers and so that the government can re-discuss regulations regarding stockpiling of goods so that they can be expanded not only to basic necessities by using the juridical normative research method and using a statutory approach, the authors get the results of this research that consumers can still get legal protection against the scarcity of a non-basic item by using the Trade Law, the Consumer Protection Law, and the Business Competition Law..

Keywords: Consumer Protection, Hoarding, Unfair Competition

\section{PENDAHULUAN}

Dalam dunia perdagangan khususnya di Indonesia seringkali ditemukan berbagai macam masalah seperti pelemahan ekonomi global, masalah mengenai impor atau ekspor, dan penimbunan barang. Perdagangan adalah suatu kegiatan transaksi terhadap barang dan atau jasa, yaitu transaksi yang bertujuan mengalihkan hak untuk memperoleh imbalan ataupun kompensasi. ${ }^{1}$

Pada tahun 2020 Walls Indonesia meluncurkan Kembali produk legendaris mereka yaitu Ice Cream "Viennetta" yang terkenal pada periode 90-an. Langkah yang diambil oleh Walls Indonesia mendapat sambutan hangat dan antusias yang tinggi dari masyarakat Indonesia khususnya generasi 90-an, namun hal ini disalah gunakan oleh oknum jahat yang tidak bertanggung jawab demi kepentingannya sendiri. Oknum tersebut memanfaatkan antusiasme masyarakat terhadap kembalinya produk legendaris dari Walls Indonesia yaitu Ice Cream Viennetta dengan cara menimbun barang tersebut dan menjualnya dengan harga yang lebih mahal. Dalam kasus penimbunan barang terhadap barang non pokok ini konsumen hanya memiliki sedikit opsi perlindungan terhadap penimbunan barang non pokok.

Sebenarnya peraturan mengenai perlindungan konsumen terhadap penimbunan barang sudah mendapat perlindugan dari Kementerian Perdagangan dalam Peraturan Menteri Perdagangan Nomor 20/M-DAG/PER/3/2017 tentang Pendaftaran Pelaku Usaha Distribusi Barang Kebutuhan Pokok, namun sayangnya peraturan tersebut hanya berlaku terhadap barang pokok saja.

Pada Pasal 29 Undang-Undang Nomor 7 tahun 2014 tentang Perdagangan menjelaskan bahwa pelaku usaha dilarang menyimpan barang kebutuhan pokok atau barang penting dalam jumlah dan waktu tertentu pada saat terjadi

1 Janus Sidabalok, HUKUM PERDAGANGAN (Perdagangan Nasional Dan Perdagangan Internasional). (Medan: Yayasan Kita Menulis, 2020), hlm. 9. 
kelangkaan barang. ${ }^{2}$

Adanya penimbunan barang maka konsumen harus mendapatkan perlindungan hukum dan mendapatkan hak konsumen dalam dunia bisnis. Hak konsumen dalam pasal 4 Undang-Undang No. 8 Tahun 1999 tentang Perlindungan Konsumen disebutkan bahwa setiap konsumen memiliki hak sebagai berikut ${ }^{3}$ :

1. Kenyamanan, keamanan dan keselamatan.

2. Dapat barang atau jasa sebanding dengan nilai tukar atau yang dijanjikan.

3. Dapat pendidikan konsumen.

4. Didengar pendapat dan keluhan.

5. Dapat kompensasi, ganti rugi atau penggantian.

Pada dasarnya konsumen di Indonesia membutuhkan perlindungan agar terhindar dari persaingan bisnis yang tidak adil. Solusi yang terbaik adalah melakukan reformasi hukum terhadap perlindungan konsumen, sebagai contoh memberikan pengenalan terhadap perlindungan hukum terhadap konsumen seperti yang diusulkan oleh Yayasan Lembaga Konsumen Indonesia (YLKI) kepada Pemerintah Indonesia pada tahun 1984 dan meninjau kembali aturan prosedur hukum terhadap perlindungan konsumen. ${ }^{4}$

Dalam hal ini campur tangan negara (pemerintah) cukup besar untuk menjamin berlangsungnya aktivitas perdagangan secara tertib, teratur, dan terencana, serta untuk menjamin terpenuhinya kebutuhan masyarakat dan kemajuan perekonomian Nasional. ${ }^{5}$

\section{Perlindungan Hukum Konsumen di Indonesia}

Awal dari suatu perkembangan hukum konsumen di dunia dimulai dari lahirnya Gerakan yang memiliki misi untuk melindungi konsumen atau dikenal sebagai consumer movements karena terdapat suatu perhatian khusus mengenai konsumen di Amerika Serikat pada periode 1960-an sampai 1970-an membuat kemajuan terhadap perlindungan konsumen menjadi lebih bermakna dan menjadi suatu objek kajian dalam bidang politik, ekonomi, sosial, dan hukum.

(Perkembangan terhadap perlindungan konsumen secara historis berawal dari gerakan perlindungan konsumen yang terdapat pada awal abad ke-19 dan pada tahun 1891 terbentuklah Liga Konsumen di New York untuk pertama kalinya. Kemudian pada tahun 1989 terbentuklah Liga Konsumen Nasional (The National Consumer's League) yang kemudian Gerakan perlindungan konsumen berkembang pesat hingga mecakup 20 negara bagian. ${ }^{6}$

Pada tahun 1914 adanya suatu kemungkinan terhadap pembentukan suatu komisi yang bergerak pada bagian perlindungan konsumen, yaitu Federal Trade Comission (FTC). Kemudian pada tahun 1930-an mulailah dipikirkan kepentingan mengenai Pendidikan untuk konsumen yang diawali dengan penulisan buku-buku mengenai konsumen dan perlindungan konsumen disertai riset-riset pendukungnya. ${ }^{7}$

Periode selanjutnya dari perkembangan perlindungan konsumen yang terjadi pada tahun 1960-an yang dimana pada periode tersebut lahirlah hukum perlindungan konsumen. Dengan lahirnya hukum perlindungan konsumen (Consumers Law) maka perlindungan konsumen merupakan satu cabang hukum yang baru. John F. Kennedy, selaku Presiden Amerika, menyampaikan consumers message dalam kongres pada tahun 1962. Pada periode tersebut membuat negara-negara lain tersadar untuk membentuk suatu peraturan atau perundang-undangan mengenai perlindungan konsumen, berikut adalah beberapa undang-undang mengenai perlindungan konsumen dari berbagai negara di dunia:

1. Singapura : The Consumer Protection (Trade Description and Safety Requirement Act, Tahun 1975).

2. Thailand : Consumer Act, Tahun 1979.

3. Jepang : The Consumer Protection Fundamental, Tahun 1968.

4. Australia : Consumers Affairs Act, Tahun 1978

5. Irlandia : Consumers Information Act, Tahun 1978.

6. Finlandia : Consumer Protection Act, Tahun 1978.

\footnotetext{
${ }^{2}$ Undang-Undang Nomor 7 tahun 2014 tentang Perdagangan

${ }^{3}$ Undang-Undang No. 8 Tahun 1999 tentang Perlindungan Konsumen

${ }^{4}$ Yusuf Shofie, Kapita Selekta Hukum Perlindungan Konsumen Di Indonesia, (Bandung: PT Citra Aditya Bakti, 2008), hlm. 5 .

${ }^{5}$ Janus Sidabalok, HUKUM PERDAGANGAN (Perdagangan Nasional Dan Perdagangan Internasional). Op. Cit., hlm. 28.

${ }^{6}$ Gunawan Widjaja dan Ahamad Yani, Hukum Tentang Perlindungan Konsumen (Jakarta: PT Gramedia Pustaka Utama, 2000) hlm. 12-13.

${ }^{7}$ Abdul Halim Barkatullah, Hukum Perlindungan Konsumen (Kajian Teoretis Dan Perkembangan Pemikiran), (Bandung: Nusa Media, 2008) hlm. 22.
} 
7. Inggris : The Consumers Protection Act, Tahun 1970, kemudian diamandemen pada Tahun 1971.

8. Kanada : The Consumers Protection Act dan The Consumers Protection Amandement Act, Tahun 1971

Masalah perlindungan konsumen di Indonesia baru mulai terdengar pada tahun 1970. Hal ini ditandai dengan lahirnya Yayasan Lembaga Konsumen Indonesia (YLKI) pada tanggal 11 Mei 1973. Pendirian Yayasan Lembaga Konsumen Indonesia (YLKI) didasari pada perhatian atas kelangkaan terhadap produk nasional yang berkualitas dan kecenderungan masyarakat untuk membeli produk impor di era 70an. ${ }^{8}$ Keinginan dan desakan masyarakat untuk melindungi dirinya dari barang yang bermutu rendah telah memacu untuk melindungi konsumen, dan sejak saat itulah Gerakan untuk merealisasikan cita-cita itu dimulai. ${ }^{9}$

Setelah sekian lama memperjuangkan gerakan terhadap perlindungan konsumen pada akhirnya terdengar oleh pemerintah negara Indonesia dan pada pasca reformasi dibentuklah RUU mengenai perlindungi konsumen. Tidak lama RUU tersebut diajukan, Presiden Indonesia langsung mengesahkan undang-undang yang termasuk salah satu aturan Nasional di Indonesia pada tanggal 20 April 1999 yang kemudian dinamakan dengan "Undang-Undang Perlindungan Konsumen" dan undang-undang tersebut efektif pada tahun berikutnya.

Proses lahirnya suatu undang-undang perlindungan konsumen yang terdiri dari 15 Bab dan 65 Pasal membutuhkan waktu 25 tahun. Sejarah pembentukannya dimulai dari : ${ }^{10}$

1. Seminar pusat studi mengenai hukum dagang dari Fakultas Hukum Universitas Indonesia tentang masalah perlindungan konsumen yang dilaksanakan pada tanggal 15-16 Desember 1975.

2. Badan Pembinaan Hukum Nasional atau yang dikenal juga sebagai BPHN, Departemen Kehakiman RI mengenai penelitian tentang perlindungan konsumen di Indonesia (proyek tahun 1979-1980).

3. Dokumen Pembangunan Hukum Nasional (DPHN) - Departemen Kehakiman, naska akademis mengenai peraturan perundang-undangan tentang perlindungan konsumen (proyek tahun 1980-1981).

4. Yayasan Lembaga Konsumen Indonesia (YLKI) mengenai perlindungan konsumen di Indonesia, suatu sumbangan pemikiran tentang rancangan UU Perlindungan Konsumen pada tahun 1981.

5. Departemen Perdagangan RI bekerja sama dengan Fakultas Hukum Universitas Indonesia dan membentuk suatu Rancangan Undang-Undang (RUU) tentang Perlindungan Konsumen pada tahun 1997

6. Dewan Perwakilan Rakyat Republik Indonesia (DPR RI) membuat Rancangan Undang-Undang (RUU) usulan inisiatif DPR tentang UU Perlindungan Konsumen, pada 1998.

\section{Dasar Hukum Perlindungan Konsumen}

Secara yuridis, pengertian perlindungan konsumen terdapat pada Pasal 1 Angka 1 Undang-Undang Nomor 8 Tahun 1999 Tentang Perlindungan Konsumen dimana yang menjelaskan bahwa perlindungan konsumen adalah upaya untuk memberikan perlindungan dan kepastian hukum terhadap konsumen. ${ }^{11}$ Terdapat 5 (lima) asas dalam upaya untuk melindungi konsumen sebagai usaha bersama dengan pihak-pihak yang terkait, pemerintahm dan pelaku usaha seperti yang tercantum dalam pasal 2 Undang-Undang Pelindungan Konsumen, yaitu :

1. Asas kemanfaatan,

Asas ini menegaskan bahwa kegiatan dalam melindungi konsumen haruslah dapat memberi manfaat yang semaksimal mungkin bagi pelaku usaha dan bagi kepentingan konsumen.

2. Asas keadilan,

Asas keadilan bertujuan agar dapat memberikan kesempatan yang adil bagi konsumen dan juga pelaku usaha demi memperoleh hak dan kewajibannya masing-masing secara adil.

3. Asas keseimbangan,

Asas keseimbangan bertujuan agar kepentingan produsen, pelaku usaha, konsumen, dan pemerintah harus diatur dan diwujudkan seimbang sesuai dengan hak dan kewajibannya masing-masing.

4. Asas keamanan dan keselamatan konsumen,

Asas keamanan dan keselamatan konsumen bertujuan agar konsumen dapat mendapatkan jaminan atas keamanan dan keselamatan dalam pemakaian dan pemanfaatan barang atau jasa yang dikonsumsi atau digunakan.

5. Asas kepastian hukum

Asas kepastian hukum atau yang dikenal dengan istilah rechtszekerheid adalah terjaminnya kepastian hukum

8 ylki.or.id. 2021. Sejarah - Yayasan Lembaga Konsumen Indonesia. <http://ylki.or.id/profil/sejarah/> [Diakses pada tanggal 27 Januari 2021].

${ }^{9}$ Gunawan Widjaja dan Ahmad Yani, Op. Cit hlm. 15-16.

${ }^{10}$ Az. Nasution, “Aspek Hukum Perlindungan Konsumen: Tinjauan Singkat UU No. 8 Tahun 1999-L.N. 1999 No. 42”, Artikel pada Teropong, Media Hukum dan Keadilan (Vol II, No. 8, Mei 2003), MaPPI-FH UI dan Kemitraan

${ }^{11}$ Ahmadi Miru, dan Sutarman Yodo. Hukum Perlindungan Konsumen. (Jakarta: PT Raja Grafindo Persada. 2008), hlm. 
terhadap konsumen dan pelaku usaha yang dijaminkan oleh negara maupun penguasa berdasarkan peraturan hukum dan agar tidak terjadi kesewenang-wenangan. ${ }^{12}$

Selain mengatur tentang hak konsumen, Undang-Undang Perlindungan Konsumen juga mengatur mengenai kewajiban konsumen, hak dan kewajiban pelaku usaha. Hak konsumen terdapat pada pasal 4 dan terdiri dari 10 (sepuluh) ayat, kewajiban konsumen terdapat pada pasal 5 (lima) dan terdiri dari 5 (lima) ayat, hak pelaku usaha terdapat pada pasal 6 (enam) dan terdiri dari 5 (lima) ayat, dan kewajiban pelaku usaha terdapat pada Pasal 7 (tujuh) yang terdiri dari 6 (enam) ayat. Dapat diambil kesimpulan bahwa dengan adanya UU Perlindungan Konsumen ini menguntungkan kedua belah pihak, yaitu konsumen dan pelaku usaha.

\section{Penimbunan Barang}

Penimbunan barang terjadi disaat jumlah barang yang dimiliki melibihi dari jumlah barang dari periode sebelumnya sementara jumlah konsumsinya masih sama. Definisi ini berlaku untuk konsumen dan organisasi di tingkat individu (mikro) dan kelompok (makro). ${ }^{13}$

Hubungan antara penimbunan barang dengan konsumsi yang diekspektasikan dipengaruhi oleh ekspektasi konsumen tentang durasi kekurangan dari barang tersebut. Apabila konsumen mengharapkan kekurangan akan terjadi dalam jangka pendek, konsumen dapat menimbun tanpa menyesuaikan konsumsinya; namun, kekurangan jangka Panjang dapat mengakibatkan penurunan konsumsi yang diharapkan. Hubungan antara penimbunan dan konsumsi melahirkan garis besar untuk teori pernimbunan yang dimana dapat diprediksi oleh konsumen, termasuk konsumsi yang diharapkan dan kekurangan yang diekspektasikan, menyebabkan penimbunan menghasilkan efek sekunder termasuk perubahan dalam inventaris penjual dan konsumsi yang diharapkan. ${ }^{14}$

Hubungan antara penimbunan dengan kelangkaan barang merupakan hubungan yang kompleks. Pertama, penimbunan barang dapat terjadi tanpa harus terjadinya kelangkaan. Kedua, penimbunan barang dapat mengakibatkan terjadinya kelangkaan dan terakhir yang sering terjadi adalah kelangkaan suatu barang dapat mengakibatkan terjadinya penimbunan. ${ }^{15}$

Berdasarkan permasalahan tersebut, maka rumusan masalah yang ditawarkan dalam penelitian ini yaitu perlindungan hukum terhadap konsumen yang kesulitan mendapat produk non pokok yang ditimbun oleh pelaku bisnis dan upaya apa yang dapat dilakukan konsumen agar mendapatkan hak-haknya akibat tidak mendapatkan barang non pokok akibat penimbunan barang

\section{METODE}

Metode penelitian ini adalah Yuridis Normatif, yang dimaksud dengan penelitian hukum normatif adalah suatu penelitian hukum baik bersifat murni maupun bersifat terapan, yang dilakukan oleh seorang peneliti hukum untuk meneliti suatu norma seperti dalam bidang-bidang keadilan, kepastian hukum, ketertiban, kemanfaaan, dan efisiensi hukum, otoritas hukum, serta norma dan doktrin hukum, yang mendasari diberlakukannya unsur-unsur tersebut ke dalam bidang hukum yang bersifat prosedural dan substansif, baik dalam bidang hukum publik, seperti prinsip-prinsip negara, kekuasaan dan kewenangan alat-alat negara, hak-hak warga negara, prinsip-prinsip perbuatan pidana atau pemidanaan dan hukuman maupun dalam bidang hukum perdata, seperti dalam bidang hukum orang, keluarga dan perkawinan, hukum benda dan perutangan, hukum kontrak, kewarisan, dan sebagainya. ${ }^{16}$

Pendekatan masalah yang digunakan adalah pendekatan perundang-undang (statute approach) dilakukan dengan mengkaji semua peraturan perundang-undangan yang berkaitan dengan permasalahan (isu hukum) yang sedang dihadapi. Pendekatan perundang-undangan atau yang juga disebut sebagai statute approach ini dilakukan dengan mempelajari konsistensi atau kesesuaian antara Undang-Undang Dasar dengan Undang-Undang, atau antara Undang-Undang yang satu dengan Undang-Undang yang lain. ${ }^{17}$

Sumber data dalam penelitian adalah subjek dari mana data dapat diperoleh. ${ }^{18}$ Sumber data yang digunakan dalam penelitian hukum normatif adalah data sekunder, yang terdiri dari 3 (tiga) sumber bahan hukum :

12 Janus Sidabalok, Hukum Perlindungan Konsumen Di Indonesia. (Bandung: Citra Aditya Bakti, 2014), hlm. 26

13 Ronald Stiff, Keith Johnson, and Khairy Ahmed Tourk (1975),"Scarcity and Hoarding: Economic and Social Explanations and Marketing Implications", in NA - Advances in Consumer Research Volume 02, eds. Mary Jane Schlinger, Ann Abor, MI : Association for Consumer Research, Pages: 203-216

${ }^{14}$ Ibid.

${ }^{15}$ Ibid hlm. 130 .

${ }^{16}$ Munir Fuady, METODE RISET HUKUM : Pendekatan Teori Dan Konsep, (Depok: PT RajaGrafindo Persada, 2018),

${ }^{17}$ Ibid.

${ }^{18}$ Suharsimi Arikunto, Prosedur Penelitian Suatu Pendekatan Praktik, (Jakarta : Rineka Cipta, 2011), hlm. 172 


\section{Sumber Data Primer}

Sumber data primer adalah suatu sumber data yang langsung dapat memberikan data kepada pengumpul data. ${ }^{19}$ Sumber Bahan Hukum Primer yaitu bahan hukum yang mempunyai otoritas (autoritatif). Bahan hukum ini terdiri dari:

a. Undang-Undang Dasar Negara Republik Indonesia 1945

b. Undang-Undang Nomor 7 tahun 2014 tentang Perdagangan

c. Undang-Undang Nomor 8 tahun 1999 tentang Perlindungan Konsumen

d. Kitab Undang-Undang Hukum Dagang

\section{Sumber Data Sekunder}

Sumber data sekunder adalah hasil pengumpulan data yang dilakukan oleh orang lain dengan maksud tersendiri yang mempunyai kategorisasi atau klasitifikasi menurut keperluan mereka. ${ }^{20}$ Dengan kata lain bahwa sumber data sekunder berfungsi sebagai sebagai pendukung analisis dari sumber data primer. Sumber data sekunder terdiri dari :

a. Buku-buku teks mengenai perlindungan konsumen dan hukum dagang serta buku-buku mengenai metode penelitian hukum guna untuk melakukan penelitian hukum ini

b. Jurnal-jurnal hukum mengenai hukum dagang ataupun perlindungan konsumen

c. Majalah atau artikel internet yang berisikan mengenai hukum

Teknik Pengumpulan Data ini menggunakan metonde analisis penelitian yuridis normatif yang bersifat kualitatif adalah penelitian yang mengacu pada norma hukum yang terdapat dalam berbagai peraturan perundangundangan, putusan pengadilan. Penelitian ini menggunakan metode analisis yuridis kualitatif, yaitu analisis yang berupa interpretasi mendalam tentang bahan-bahan hukum sebagaimana umumnya penelitian hukum normatif. Selanjutnya hasil analisis tersebut akan penulis hubungkan dengan permasalahan dalam penelitian ini untuk menghasilkan suatu penelitian objektif guna menjawab permasalahan dalam penelitian.

\section{HASIL DAN PEMBAHASAN \\ Perlindungan Hukum Terhadap Konsumen yang Kesulitan Mendapat Produk Non Pokok yang Ditimbun Oleh Pelaku Bisnis}

Permasalahan terhadap penimbunan barang non pokok oleh oknum pelaku usaha yang membuat barang non pokok menjadi langka dan dijual di pasaran dengan harga yang jauh lebih mahal dari harga asli menggambarkan bahwa pelanggaran tersebut telah melanggar serta mengancam kepentingan konsumen. ${ }^{21}$

Dalam hal ini perlindungan konsumen terhadap penimbunan barang non pokok dapat menggunakan UndangUndag Perdagangan, Undang-Undang Perlindungan Konsumen, dan juga dapat menggunakan Undang-Undang Persaingan Usaha Tidak Sehat

\section{UU Perdagangan}

Seperti tujuan utamanya, UU Perdagangan bertujuan untuk memajukan kesejahteraan umum melalui pelaksanaan terhadap demokrasi ekonomi dengan menggunakan prinsip kebersamaan, berkelanjutan, efisiensi berkeadilan, kemandirian, berwawasan lingkungan, menjaga keseimbangan kemajuan, dan juga sebagai kesatuan ekonomi nasional sebagaimana telah ditentukan oleh Undang-Undang Dasar Negara Republik Indonesia 1945.

Dalam konteks permasalahan dalam kasus penimbunan barang non pokok ini adanya regulasi mengenai perdagangan sendiri telah menunjukkan bahwa dalam kegiatan perekonomian, khususnya dalam perdagangan, peran pemerintah dalam perlindungan barang non pokok yaitu dengan cara membentuk Komite Perdagangan Nasional.

Salah satu tujuan dari Komite Perdagangan Nasional memiliki tujuan seperti yang tertuang pada Pasal 97 ayat (4) huruf a adalah memberikan masukan untuk pemerintah untuk menentukan kebijakan serta regulasi dalam bidang perdagangan, dalam hal ini Komite Perdagangan Nasional dapat menampung aspirasi konsumen untuk memerikan perlindungan terhadap penimbunan barang non pokok.

\section{UU Perlindungan Konsumen}

Tujuan dari UU Perlindungan Konsumen adalah untuk meningkatkan harkat dan martabat konsumen dengan cara meningkatkan kepedulian, kesadaran, pengetahuan, kemandiriam, dan kemampuan konsumen untuk melindungi dirnya sendiri serta UU Perlindungan Konsumen hadir untuk melengkapi perlindungan hukum terhadap konsumen.

${ }^{19}$ Sugiono, METODE PENELITIAN PENDIDIKAN : Pendekatan Kuantitatif, Kualitatif Dan R\&D. (Bandung: Alfabeta, 2008), hal. 308

${ }^{20}$ S, Nasution, METODE RESEARCH : (Penelitian Ilmiah), (Bandung: Bumi Aksara, 2006), hal. 143.

${ }^{21}$ Mohammad Faisol Soleh. "Penimbunan Alat Pelindung Diri Pada Masa Pandemi Covid-19: Kajian Hukum Pidana Bidang Perlindungan Konsumen". Undang: Jurnal Hukum Vol. 3, No. 1 (2020) : 13 
Seringkali ditemukan kasus ketidakpuasan konsumen terhadap barang non pokok yang dianggap sangat mahal atau harganya tidak sesuai dengan harga pasarannya. Beragam spekulasi mulai dari kualitas sampai adanya kecurigaan terhadap pelaku usaha yang menimbun barang non pokok tersebut. Maka sesuai dengan pasal 4 ayat (4) UU Perlindungan Konsumen bahwa apabila terjadi kasus kelangkaan barang akibat terjadinya penimbunan barang non pokok yang terjadi di masyarakat, konsumen berhak didengar pendapat serta keluhannya terhadap barang/jasa yang digunakan.

\section{UU Persaingan Usaha}

Undang-Undang No. 5 Tahun 1999 Tentang Larangan Praktek Monopoli dan Persaingan Usaha Tidak Sehat memiliki tujuan untuk mewujudkan suatu iklim usaha yang sehat, menjaga agar tidak terjadinya praktik monopoli dan persaingan usaha tidak sehat lainnya, dan agar terciptanya efektivitas dan juga efisiensi dalam suatu kegiatan usaha. Dengan begitu UU Persaingan Usaha menghendaki agar kegiatan usaha dapat berlangsung secara sehat tanpa adanya praktik monopoli dan berbagai macam persaingan usaha tidak sehat lainnya yang harus segera dicegah agar tidak mengganggu kepentingan umum. ${ }^{22}$

Dalam hubungannya dengan permasalahan yang dibahas dalam artikel ini, yaitu penimbunan barang non pokok, maka Undang-Undang Persaingan Usaha dapat digunakan pada saat penimbunan barang non pokok tersebut termasuk dalam bentuk persaingan usaha tidak sehat dan praktik monopoli. Terdapat 10 (sepuluh) jenis dab 6 (enam) kegiatan yang dilarang dalam UU Persaingan ini. Dalam artikel ini tidak seluruh kegiatan yang dilarang itu relevan, maka dari itu bagian berikut ini hanyalah membahas mengenai larangan dari perjanjian dan kegiatan yang memiliki relevansi. ${ }^{23}$

Yang pertama adalah oligopoli. Larangan terhadap oligopoli terdapat pada pasal 4 ayat (1) Undang-Undang Persaingan Usaha dimana disebutkan bahwa pelaku usaha dilarang membuat perjanjian dengan pelaku usaha lain secara Bersama-sama untuk melakukan penguasaan suatu produksi dan atau pemasaran barang dan jasa yang dimana hal tersebut dapat menyebabkan terjadinya praktik monopoli dan persaingan usaha tidak sehat. Dalam hukum persaingan usaha, ketentuan ini juga dikenal dengan perjanjian oligopoli, yaitu suatu perjanjian yang menciptakan struktur pasar yang di mana dalam pasar tersebut hanya terdiri dari sedikit pelaku usaha, sehingga mempengaruhi perilaku perusahaan dan dapat mempengaruhi harga pasar. Karena adanya faktor yang saling mempengaruhi, maka dalam pasar oligopoly tersebut sudah terjadi interdependensi antar pelaku usaha yang bersaing, yang memaksa pelaku usaha untuk mempertimbangkan reaksi dari pesaingnya Ketika membuat keputusan dalam menetapkan suatu harga jual.

Akan tetapi dalam perjanjian oligopoli terdapat suatu ketentuan yang disebut sebgai rule of reason yang artinya perjanjian itu sendiri tidak dilarang selama perjanjian tersebut tidak mengakibatkan terjadinya praktik monopoli atau persaingan usaha tidak sehat. ${ }^{24}$ Apabila mengacu pada UU Persaingan Usaha, apabila terdapat 2 (dua) atau (tiga) pelaku usaha menguasi lebih dari 75\% (tujuh puluh lima persen) pangsa pasar terhadap satu jenis barang maka dapat diduga bahwa sudah terjadi praktik oligopoli yang dilakukan oleh kelompok pelaku usaha. ${ }^{25}$

Larangan selanjutnya adalah kartel. Larangan terhadap kartel terdapat pada pasal 11 UU Persaingan Usaha yang menyatakan bahwa pelaku usaha dilarang membuat perjanjain dengan pelaku usaha pesaingnya dengan maksud untuk mempengaruhi harga dengan mengatur produksi, pemasaran dan atau jasa yang dapat mengakibatkan terjadinya suatu praktik monopoli dan persaingan usaha tidak sehat. Berdasarkan kentutan tersebut, maka kartel dapat berupa suatu pengaturan produksi atau pemsaran dari suatu barang.

Ketentuan mengenai kartel terdapat pada pasal 11 UU Persaingan Usaha sesungguhnya bersifat rule of reason. Hal ini disebabkan karena terdapat frasa yang berbuni "dapat mengakibatkan" yang berarti bahwa perjanjian kartel ini menjadi terlarang apabila dapat mengakibatkan praktik monopoli dan persaingan usaha tidak sehat dimana yang berarti perjanjian ini sebenarnya tidak dilarang dengan syarat perjanjian tersebut tidak menimbulkan praktik monopoli dan atau persaingan usaha tidak sehat.

Selanjutnya adalah larangan terhadap praktik monopoli yang terdapat pada pasal 17 ayat (1) UU Persaingan Usaha dimana pelaku usaha dilarang melakukan penguasaan atas produksi dan pemasaran terhadap suatu barang atau jasa yang dapat mengakibatkan terjadinya praktik monopoli dan persaingan usaha tidak sehat. Larangan monopoli ini berbeda dari 3 (tiga) larangan sebelumnya yang dimana larangan tersebut merupakan bagian dari suatu perjanjian yang berarti perjanjian tersebut melibatkan lebih dari satu pelaku usaha, melainkan dapat dilakukan oleh hanya satu pelaku usaha ataupun kelompok pelaku usaha saja. Praktik monopoli dapat diduga apabila satu pelaku usaha ataupun satu kelompok pelaku usaha menguasai lebih dari $50 \%$ (lima puluh persen) dari pangsa pasar terhadap satu jenis barang

${ }^{22}$ Mohammad Faisol Soleh. Op. Cit. hlm. 19

${ }^{23}$ Ibid.

${ }^{24}$ Andi Fahmi Lubis, dkk, Hukum Persaingan Usaha: Buku Teks, (Jakarta: Komisi Pengawas Persaingan Usaha), hlm. 92.93.

${ }^{25}$ Pasal 4 ayat (2) UU Persaingan Usaha 
atau jasa tertentu. ${ }^{26}$ Dikarenakan terdapat kalimat "dapat mengakibatkan" maka ketentuan tersebut termasuk rule of reason dimana yang memiliki arti bahwa penguasaan tersebut harus berdampak kepada praktik monopoli atau persaingan usaha tidak sehat. Tidak terkendalinya suatu persaingan usaha dapat mengakibatkan praktik monopoli yang dimana hal tersebut tidak sejalan dengan prinsip-prinsip dari persaingan usaha. Dalam praktik persaingan usaha, kegiatan monopoli itu sendiri ada yang merugikan dan ada juga yang menguntungkan perekonomian masyarakat. Maka dari itu pengertian dari jenis-jenis monopoli ini perlu dijelaskan lebih lanjur guna untuk membedakan antara monopoli yang memberikan keuntungan bagi masyarakat dan monopoli yang merugikan masyarakat ${ }^{27}$. Karena hal tersebut maka terdapat beberapa bentuk monopoli ${ }^{28}$

1. Praktik monopoli yang terjadi karena kekuatan besar yang diberikan oleh negara berupa hak paten secara eksklusif

2. Praktik monopoli yang terjadi dikarenakan diberikan kepercayaan oleh pasal 33 UUD 1945 yang berisi bahwa negara dapat menguasai kekayaan alam yang terkandung di dalamnya

Agar ketentuan mengenai monopolo dapat digunakan untuk menindaklanjuti suatu aktivitas penimbunan t non pokok, maka terdapa 2 (dua) hal yang harus dipenuhi yaitu :

1. Pelaku penimbunan barang merupakan satu pelaku usaha ataupun satu kelompok usaha dan menguasai suatu produksi atau pemasaran barang non pokok yang melebihi 50\% (lima puluh persen);

2. Penimbunan barang non pokok mengakibatkan terjadinya suatu praktik monopoli atau persaingan usaha tidak sehat.

\section{Upaya Hukum Apabila Timbulnya Kerugian Konsumen \\ Non Litigasi}

Menurut Pasal 47 UU Perlindungan Konsumen, upaya hukum non litigasi yang dapat diambil oleh konsumen dilaksanakan dengan tujuan untuk mencapai kesepakatan mengenai besar dan bentuk ganti rugi serta mengenai Tindakan tertentu untuk menjamin agar tidak terjadi Kembali kerugian yang akan diderita konsumen.

Dalam UU Perlindungan Konsumen pasal 45 ayat (4) menjelaskan apabila para pihak yang bersengketa telah memilih untuk menyelesaikan masalahnya di luar pengadilan maka gugatan yang melalui pengadilan hanya dapat dilaksanakan apabila penyelesaian melalui jalur di luar pengadilan dinyatakan tidak berhasil oleh pada pihak yang bersengketa. Penyelesaian sengketa konsumen secara non litigasi dapat dilaksanakan melalui Badan Penyelesaian Sengketa Konsumen (BPSK), Yayasan Lembaga Konsumen Indonesia (YLKI), Direktorat Perlindungan Konsumen Disperindag, dan pelaku usaha sendiri. ${ }^{29}$

Sesuai dengan tujuan didirikannya Yayasaan Lembaga Konsumen Indonesia (YLKI), dalam pasal 44 ayat 1 dan 2 UU Perlindungan Konsumen YLKI berperan aktif dalam mewujudkan perlindungan konsumen dan merupakan suatu Lembaga swadaya yang diakui oleh pemerintah. Terdapat 4 (empat) cara untuk melakukan pengaduan terhadap permasalahan yang dialami oleh konsumen yaitu dapat melalui surat, telpon, email, dan dapat juga dating langsung ke kantor YLKI.

Tahap pertama yang harus dilakukan konsumen dalam hal pengajuan ke YLKI yaitu dengan cara menngisi atau menulis mengenai masalah yang dihadapi dengan memperhatikan hal-hal berikut; identitas dan alamat lengkap konsumen, kronologis masalah yang dihadapi, dan juga menyertakan barang bukti. Selanjutnya YLKI akan memproses berkas aduan yang dilayangkan oleh konsumen. Setelah pihak YLKI selesai memproses dan mempelajari masalah yang dihadapi konsumen maka Langkah selanjutnya yang dilakukan oleh YLKI adalah memberikan surat kepada pelaku usaha agar dapat memberikan keterangannya kepada Yayasan Lembaga Konsumen Indonesia (YLKI). Mulai dari sini, Yayasan Lembaga Konsumen Indonesia (YLKI) menjadi jembatan antara konsumen dengan pelaku usaha baik secara langsung maupun tidak langsung. Upaya yang dapat dilakukan oleh konsumen melalui Direktorat Perlindungan Konsumen Disperindag hampir sama dengan yang dilakukan oleh Yayasan Lembaga Konsumen Indonesia (YLKI).

Perbedaan antara Direktorat Perlindungan Konsumen Disperindag dengan Yayasan Lembaga Konsumen Indonesia (YLKI) terdapat saat seorang pelaku usaha dimintai keterangan mengenai masalah yang terjadi. Apabila ditemukan hak konsumen yang dilanggar maka pelaku usaha dapat mematuhi ketentuan yang telah ditetapkan dan izin usaha pelaku usaha yang dikeluarkan oleh Disperindag dapat dicabut. Pencabutan izin usaha sangat efektif memberikan efek jera terhadap pelaku usaha yang melanggar hak - hak konsumen. Walaupun terdapat wadah yang disediakan pemerintah untuk menampung pengaduan konsumen akan tetapi masih jarang dilakukan konsumen dikarenakan kurangnya sosialisasi sehingga masyarakat tidak mengetahui adanya sarana pengaduan untuk konsuen

\footnotetext{
${ }^{26}$ Pasal 17 ayat (2) huruf c UU Persaingan Usaha

27 Galuh Puspaningrum, Hukum Persaingan Usaha, Yogyakarta : Aswaja Pressindo, 2013.

${ }^{28}$ Mashur Malaka, "Praktek Monopoli dan Persaingan Usaha". Jurnal Al-'Adl Vol. 7, No. 2 (Juli 2014).

${ }^{29}$ Edmon Makarim, Pengantar Hukum Telematika, (Jakarta: PT Raja Grafindo Persada, 2005), hlm. 159
} 
yang disediakan oleh Disperindag. ${ }^{30}$

Dari penjelasan di atas, terlihat jelas bahwa pemerintah maupun Lembaga swadaya masyarakat telah menyediakan wadah untuk para konsumen yang ingin menyelesaikan sengketa yang dialami oleh konsumen dan juga untuk membela hak konsumen yang telah dilanggar oleh pelaku usaha. Hal ini harusnya menjadikan konsumen sadar dan agar lebih berani untuk mengadukan permasalahan yang dialami dikarenakan dalam prakteknya konsumen masih enggan untuk melaporkan pelanggaran yang terjadi terhadap konsumen.

\section{Litigasi}

Pada pasal 45 ayat (1) UU No. 8 Tahun 1999 tentang Perlindungan Konsumen menjelaskan bahwa setiap konsumen yang merasa hak - haknya dirugikan atau dilanggar dapat menggugat pelaku usaha melalui Lembaga yang bertugas untuk menyelesaikan sengketa antara konsumen dengan pelaku usaha atau dapat juga melalui peradilan yang berada di pengadilan umum.

Dalam pasal 46 ayat (1) UU Perlindungan Konsumen disebutkan terdapat pihak - pihak yang boleh mengajukan gugatannya ke pengadilan, berikut adalah pihak - pihak tersebut ${ }^{31}$ :

a. Seorang konsumen yang dirugikan atau ahli warisnya.

b. Sekelompok konsumen yang mempunyai kepentingan yang sama.

c. Lembaga perlindungan konsumen swadaya masyarakat yang memenuhi syarat, yaitu berbentuk badan hukum atau yayasan yang tujuan didirikannya lembaga ini adalah untuk kepentingan konsumen.

d. Pemerintah atau instansi terkait

Ada beberapa hal yang perlu diperhatikan oleh konsumen dalam mengajukan gugatan ke pengadilan sengketa konsumen, yaitu:

a. Segala bentuk kerugian yang dialami oleh konsumen dapat diajukan ke pengadilan tanpa melihat besar atau kecilnya kerugian yang diderita oleh konsumen. Hal ini telah diizinkan dengan memperhatikan hal - hal berikut ini $^{32}$ :

1. Kepentinga pihak konsumen tidak dapat dihitung kerugiannya dari nilai uang

2. Keadilan di mata hukum yang berarti seluruh konsumen dapat perlindungan hukum termasuk konsumen kecil maupun konsumen miskin

3. Demi menjaga integritas dari badan - badan peradilan

4. Dalam hal pembuktian, ada atau tidaknya suatu unsur kesalahan merupakan tanggung jawab dari pelaku usaha, hal ini karena pada pasal 19 juncto pasal 28 UU Perlindungan Konsumen menganut asas pertanggung jawaban produk (product liability). Hal ini berbeda dari teori beban pembuktian pada acara biasa yang dimana beban pembuktiannya merupakan tanggung jawab dari penggugat itu sendiri (konsumen) untuk membuktikan adanya unsur kesalahan, maka dalam hal pengajuan gugatan kepada pelaku usaha, konsumen hanya perlu menunjukkan bahwa terdapat hak konsumen yang dilanggar oleh pelaku usaha.

5. bahwa pembuktian ada atau tidaknya suatu unsur kesalahan merupakan beban dan tanggung jawab dari pelaku usaha, hal ini disebabkan karena UU Perlindungan Konsumen menganut asas pertanggungan jawab produk (product liability) sebagaimana diatur dalam Pasal 19 juncto Pasal 28 UU Perlindungan Konsumen. ${ }^{33}$

Dalam hukum terdapat prinsip bahwa setiap orang yang melakukan sesuatu yang mengakibatkan kerugian bagi orang lain maka haruslah bertanggung jawab terhadap apa yang telah diperbuatnya. Maka sebab itu konsumen dapat menuntut kepada pelaku usaha untuk memberikan kompensasi atau ganti rugi. Pasal 19 ayat (2) UU Perlindungan konsumen menyatakan bahwa ganti rugi yang harus dipenuhi oleh pelaku usaha dapat meliputi pemgembalian uang, penggantian terhadap barang ataupun jasa yang sejenis, perawatan, dan juga pemberian santunan sesuai dengan ketentuan perundang-undangan.

\section{SIMPULAN}

Dalam hal ini perlindungan konsumen terhadap penimbunan barang non pokok dapat menggunakan UndangUndag Perdagangan, Undang-Undang Perlindungan Konsumen, dan juga dapat menggunakan Undang-Undang Persaingan Usaha Tidak Sehat

1. UU Perdagangan

UU Perdagangan bertujuan untuk memajukan kesejahteraan umum melalui pelaksanaan terhadap demokrasi

\footnotetext{
${ }^{30}$ Edmon Makarim, Op. Cit. hlm. 45

${ }^{31}$ Pasal 46 ayat (1) Undang - Undang Nomor 8 Tahun 1999 Tentang Perlindungan Konsumen

32 Janus Sidabalok. Hukum Perlindungan Konsumen Di Indonesia. Op. Cit. hlm. 148

${ }^{33}$ Siahaan, N. H. T, Aa Sudirman, and Yuniawan W Nugroho. 2005. Hukum Konsumen. Bogor: Panta Rei. hlm. 17
} 
ekonomi dengan menggunakan prinsip kebersamaan, berkelanjutan, efisiensi berkeadilan, kemandirian, berwawasan lingkungan, menjaga keseimbangan kemajuan, dan juga sebagai kesatuan ekonomi nasional sebagaimana telah ditentukan oleh Undang-Undang Dasar Negara Republik Indonesia 1945.

Salah satu tujuan dari Komite Perdagangan Nasional memiliki tujuan seperti yang tertuang pada Pasal 97 ayat (4) huruf a adalah memberikan masukan untuk pemerintah untuk menentukan kebijakan serta regulasi dalam bidang perdagangan, dalam hal ini Komite Perdagangan Nasional dapat menampung aspirasi konsumen untuk memerikan perlindungan terhadap penimbunan barang non pokok.

2. UU Perlindungan Konsumen

Tujuan dari UU Perlindungan Konsumen adalah untuk meningkatkan harkat dan martabat konsumen dengan cara meningkatkan kepedulian, kesadaran, pengetahuan, kemandiriam, dan kemampuan konsumen untuk melindungi dirnya sendiri serta UU Perlindungan Konsumen hadir untuk melengkapi perlindungan hukum terhadap konsumen.

Seringkali ditemukan kasus ketidakpuasan konsumen terhadap barang non pokok yang dianggap sangat mahal atau harganya tidak sesuai dengan harga pasarannya. Sesuai dengan pasal 4 ayat (4) UU Perlindungan Konsumen bahwa apabila terjadi kasus kelangkaan barang akibat terjadinya penimbunan barang non pokok yang terjadi di masyarakat, konsumen berhak didengar pendapat serta keluhannya terhadap barang/jasa yang digunakan.

3. UU Persaingan Usaha

Undang-Undang No. 5 Tahun 1999 Tentang Larangan Praktek Monopoli dan Persaingan Usaha Tidak Sehat memiliki tujuan untuk mewujudkan suatu iklim usaha yang sehat, menjaga agar tidak terjadinya praktik monopoli dan persaingan usaha tidak sehat lainnya, dan agar terciptanya efektivitas dan juga efisiensi dalam suatu kegiatan usaha. Dengan begitu UU Persaingan Usaha menghendaki agar kegiatan usaha dapat berlangsung secara sehat tanpa adanya praktik monopoli dan berbagai macam persaingan usaha tidak sehat lainnya yang harus segera dicegah agar tidak mengganggu kepentingan umum.

Dalam artikel ini tidak seluruh kegiatan yang dilarang itu relevan, maka dari itu bagian berikut ini hanyalah membahas mengenai larangan dari perjanjian dan kegiatan yang memiliki relevansi :

1. Oligopoli

Larangan terhadap oligopoli terdapat pada pasal 4 ayat (1) Undang-Undang Persaingan Usaha dimana disebutkan bahwa pelaku usaha dilarang membuat perjanjian dengan pelaku usaha lain secara Bersama-sama untuk melakukan penguasaan suatu produksi dan atau pemasaran barang dan jasa yang dimana hal tersebut dapat menyebabkan terjadinya praktik monopoli dan persaingan usaha tidak sehat. Dalam hukum persaingan usaha, ketentuan ini juga dikenal dengan perjanjian oligopoli, yaitu suatu perjanjian yang menciptakan struktur pasar yang di mana dalam pasar tersebut hanya terdiri dari sedikit pelaku usaha, sehingga mempengaruhi perilaku perusahaan dan dapat mempengaruhi harga pasar.

2. Kartel

Larangan terhadap kartel terdapat pada pasal 11 UU Persaingan Usaha yang menyatakan bahwa pelaku usaha dilarang membuat perjanjain dengan pelaku usaha pesaingnya dengan maksud untuk mempengaruhi harga dengan mengatur produksi, pemasaran dan atau jasa yang dapat mengakibatkan terjadinya suatu praktik monopoli dan persaingan usaha tidak sehat. Berdasarkan kentutan tersebut, maka kartel dapat berupa suatu pengaturan produksi atau pemsaran dari suatu barang.

3. Monopoli

Larangan terhadap praktik monopoli yang terdapat pada pasal 17 ayat (1) UU Persaingan Usaha dimana pelaku usaha dilarang melakukan penguasaan atas produksi dan pemasaran terhadap suatu barang atau jasa yang dapat mengakibatkan terjadinya praktik monopoli dan persaingan usaha tidak sehat. Larangan monopoli ini berbeda dari 3 (tiga) larangan sebelumnya yang dimana larangan tersebut merupakan bagian dari suatu perjanjian yang berarti perjanjian tersebut melibatkan lebih dari satu pelaku usaha, melainkan dapat dilakukan oleh hanya satu pelaku usaha ataupun kelompok pelaku usaha saja.

Dalam pembahasan di atas dapat disimpulkan, pertama bahwa tidak terdapat perlindungan konsumen terhadap kelangkaan barang non pokok yang disebabkan oleh penimbunan barang, namun terdapat beberapa upaya yang dapat konsumen lakukan salah satunya adalah mengajukan aduan ke Yayasan Lembaga Konsumen Indonesia (YLKI), Badan Penyelesaian Sengketa Konsumen (BPSK) atau Badan Perlindugan Konsumen Nasional (BPKN).

Terdapat 4 (empat) cara untuk melakukan pengaduan terhadap permasalahan yang dialami oleh konsumen yaitu dapat melalui surat, telpon, email, dan dapat juga dating langsung ke kantor YLKI.

Tahap pertama yang harus dilakukan konsumen dalam hal pengajuan ke YLKI yaitu dengan cara menngisi atau menulis mengenai masalah yang dihadapi dengan memperhatikan hal-hal berikut; identitas dan alamat lengkap konsumen, kronologis masalah yang dihadapi, dan juga menyertakan barang bukti. Selanjutnya YLKI akan 
memproses berkas aduan yang dilayangkan oleh konsumen. Setelah pihak YLKI selesai memproses dan mempelajari masalah yang dihadapi konsumen maka Langkah selanjutnya yang dilakukan oleh YLKI adalah memberikan surat kepada pelaku usaha agar dapat memberikan keterangannya kepada Yayasan Lembaga Konsumen Indonesia (YLKI). Mulai dari sini, Yayasan Lembaga Konsumen Indonesia (YLKI) menjadi jembatan antara konsumen dengan pelaku usaha baik secara langsung maupun tidak langsung.

Berikutnya adalah perlindungan hukum terhadap konsumen yang kesulitan mendapat produk non pokok yang ditimbun oleh pelaku bisnis mengacu kepada :

1. Undang-Undang Nomor 7 Tahun 2014 Tentang Perdagangan

2. Undang-Undang Nomor 8 Tahun 1999 Tentang Perlindungan Konsumen

3. Undang-Undang Nomor 5 Tahun 1999 Tentang Persaingan Usaha

Dan yang terakhir adalah terdapat 2 (dua) upaya yang dapat dilakukan oleh konsumen apabila konsumen mengalami kerugian, yaitu :

1. Non Litigasi

Menurut Pasal 47 UU Perlindungan Konsumen, upaya hukum non litigasi yang dapat diambil oleh konsumen dilaksanakan dengan tujuan untuk mencapai kesepakatan mengenai besar dan bentuk ganti rugi serta mengenai Tindakan tertentu untuk menjamin agar tidak terjadi Kembali kerugian yang akan diderita konsumen.

Dalam UU Perlindungan Konsumen pasal 45 ayat (4) menjelaskan apabila para pihak yang bersengketa telah memilih untuk menyelesaikan masalahnya di luar pengadilan maka gugatan yang melalui pengadilan hanya dapat dilaksanakan apabila penyelesaian melalui jalur di luar pengadilan dinyatakan tidak berhasil oleh pada pihak yang bersengketa. Penyelesaian sengketa konsumen secara non litigasi dapat dilaksanakan melalui Badan Penyelesaian Sengketa Konsumen (BPSK), Yayasan Lembaga Konsumen Indonesia (YLKI), Direktorat Perlindungan Konsumen Disperindag, dan pelaku usaha sendiri.

2. Litigasi

Dalam hukum terdapat prinsip bahwa setiap orang yang melakukan sesuatu yang mengakibatkan kerugian bagi orang lain maka haruslah bertanggung jawab terhadap apa yang telah diperbuatnya. Maka sebab itu konsumen dapat menuntut kepada pelaku usaha untuk memberikan kompensasi atau ganti rugi. Pasal 19 ayat (2) UU Perlindungan konsumen menyatakan bahwa ganti rugi yang harus dipenuhi oleh pelaku usaha dapat meliputi pemgembalian uang, penggantian terhadap barang ataupun jasa yang sejenis, perawatan, dan juga pemberian santunan sesuai dengan ketentuan perundang-undangan.

\section{DAFTAR PUSTAKA}

\section{Buku}

Arikunto, Suharsimi. Prosedur Penelitian Suatu Pendekatan Praktik. Jakarta: Rineka Cipta, 2011.

Barkatullah, Abdul Halim. Hukum Perlindungan Konsumen (Kajian Teoretis Dan Perkembangan Pemikiran). Bandung: Nusa Media, 2008.

Fuady, Munir, METODE RISET HUKUM : Pendekatan Teori Dan Konsep. Depok: PT RajaGrafindo Persada, 2018. Lubis, Andi Fahmi dkk, Hukum Persaingan Usaha: Buku Teks. Jakarta: Komisi Pengawas Persaingan Usaha, 2017.

Makarim, Edmon. Pengantar Hukum Telematika. Jakarta: PT Raja Grafindo Persada, 2005.

Miru, Ahmadi, dan Sutarman Yodo, Hukum Perlindungan Konsumen. Jakarta: PT Raja Grafindo Persada, 2008.

Nasution, S., METODE RESEARCH : (Penelitian Ilmiah), Bandung: Bumi Aksara, 2006.

Puspaningrum, Galuh. Hukum Persaingan Usaha, Yogyakarta : Aswaja Pressindo, 2013,

Shofie, Yusuf, Kapita Selekta Hukum Perlindungan Konsumen Di Indonesia, Bandung: PT Citra Aditya Bakti, 2008.

Siahaan, Nommy Horas Thombang, dkk. Hukum Konsumen. Bogor: Panta Rei, 2005.

Sidabalok, Janus. HUKUM PERDAGANGAN (Perdagangan Nasional Dan Perdagangan Internasional), Medan: Yayasan Kita Menulis, 2020.

Sidabalok, Janus. Hukum Perlindungan Konsumen Di Indonesia. Bandung: Citra Aditya Bakti, 2014

Sugiono, METODE PENELITIAN PENDIDIKAN : Pendekatan Kuantitatif, Kualitatif Dan R\&D. Bandung: Alfabeta, 2008.

Widjaja, Gunawan dan Ahmad Yani. Hukum Tentang Perlindungan Konsumen. Jakarta: PT Gramedia Pustaka Utama, 2000.

Wiratna, Sujarweni, Metodologi Penelitian Lengkap, Praktis Dan Mudah Dipahami. Yogyakarta: Pustaka Baru Press, 2014.

\section{Internet}

ylki.or.id. 2021. Sejarah - Yayasan Lembaga Konsumen Indonesia. <http://ylki.or.id/profil/sejarah/> [Diakses pada tanggal 27 Januari 2021]. 


\section{Jurnal/Artikel}

Malaka Mashur, "Praktek Monopoli dan Persaingan Usaha”. Jurnal Al-'Adl Vol. 7, No. 2 (Juli 2014).

Nasution, Az, "Aspek Hukum Perlindungan Konsumen: Tinjauan Singkat UU No. 8 Tahun 1999-L.N. 1999 No. 42”, Media Hukum dan Keadilan Vol II, No. 8, (Mei 2003), MaPPI-FH UI dan Kemitraan

Ronald Stiff, Keith Johnson, and Khairy Ahmed Tourk,"Scarcity and Hoarding: Economic and Social Explanations and Marketing Implications", in NA - Advances in Consumer Research Volume 02, (1975)

Soleh, Mohammad Faisol. "Penimbunan Alat Pelindung Diri Pada Masa Pandemi Covid-19: Kajian Hukum Pidana Bidang Perlindungan Konsumen". Undang: Jurnal Hukum Vol. 3, No. 1 (2020).

\section{Peraturan Perundang-undangan}

Republik Indonesia, Undang-Undang Perdagangan, Undang-Undang Nomor 7 Tahun 2014, Lembaran Negara Republik Indonesia Tahun 2014 Nomor 45, Tambahan Lembaran Negara Republik Indonesia Nomor 5512.

Republik Indonesia, Undang-Undang Perlindungan Konsumen, Undang-Undang No. 8 Tahun 1999, Lembaran Negara Republik Indonesia Tahun 1999 Nomor 42, Tambahan Lembaran Negara Republik Indonesia Nomor 3821. 